International Journal of Current Microbiology and Applied Sciences

ISSN: 2319-7706 Volume 8 Number 01 (2019)

Journal homepage: http://www.ijcmas.com

Original Research Article

https://doi.org/10.20546/ijcmas.2019.801.254

\title{
Biochemical Characterization and Correlations in Brassica juncea Genotypes
}

\author{
Anubhuti Sharma ${ }^{1}$, Manoj Aacharya ${ }^{2}$, H. Punetha $^{3}$, Sanjula Sharma ${ }^{4}$, \\ Nisha Kumari ${ }^{5}$ and P.K. Rai ${ }^{1}$ \\ ${ }^{1}$ Directorate of Rapeseed Mustard Research (ICAR), Sewar, Bharatpur 321303 \\ (Rajasthan) India \\ ${ }^{2}$ CSKHP Agricultural University Shivalik Agricultural Research and Extension Centre \\ Kangra-176 001 (H.P.), India \\ ${ }^{3}$ G.B. Pant University of Agriculture and Technology, Pantnagar 263145 (Uttarakhand), \\ India \\ ${ }^{4}$ Punjab Agricultural University Ludhiana-141 004 (Punjab), India \\ ${ }^{5}$ CCS Haryana Agricultural University, Hissar-125004 (Haryana), India \\ *Corresponding author
}

\begin{abstract}
A B S T R A C T
Keywords

Brassica juncea,

Soxhlet method,

Glucosinolate,

Phytic acid

Article Info

Accepted:

17 December 2018

Available Online:

10 January 2019

Twenty four genotypes from germplasm were taken to evaluate oil content, oil stability index, erucic acid, total glucosinolate content, total protein content and phytic acid. The assayed genotypes contained $35.54 \%$ to $40.96 \%$ oil content, 0.79 to 1.34 oil stability index, $0.31 \%$ to $49.79 \%$ erucic acid, 16.20 to $103.96 \mu \mathrm{mol} / \mathrm{g}$ total glucosinolate content of defatted seedmeal, $34.86 \%$ to $38.79 \%$ protein content and $1.77 \%$ to $2.84 \%$ phytic acid. The objective of this work is to characterize and correlate the biochemical parameters for neutraceutical study in brassica. The study confirmed the significant genetic variability in brassica kernels with respect to oil content, glucosinolates, total protein, omega ratio, oil stability index and phytic acid.
\end{abstract}

\section{Introduction}

Identification of germplasm with rich nutritional profile is very much essential for eradicating the problem of malnutrition globally. In recent years, consumer's view has undergone a drastic change as of now they are not only concerned about what they eat but also on the impact of consumed ingredients on their health. One of the important components in our diets is oil which is the most concentrated source of energy. In India, major contributors towards vegetable oils are rapeseed-mustard $(31 \%)$, soybean $(26 \%)$ and groundnut (24\%). Other crops viz., sunflower, sesame and safflower contribute only $18 \%$ 
towards vegetable oil (DAC 2017). The oil utilization, whether for edible (cooking) or non-edible (industrial) purpose, solely depends upon its fatty acid profile. The oil to be used for edible purpose has to follow certain guidelines as recommended by global health agencies.

As per American Heart Association (AHA) and WHO/FAO recommendations, saturated fatty acids (SFA) should not be above $10 \%$. Out of so many vegetable oils available in market, only mustard fulfills the requirement as it has around $2.5-8.6 \%$ of SFA (palmitic $\mathrm{C}_{16: 0}+$ stearic $\mathrm{C}_{18: 0}$ ). Apart from this, mustard oil also contains oleic $\left(\mathrm{C}_{18: 1}\right)$, linoleic $\left(\mathrm{C}_{18: 2}\right.$; $\omega 6)$, linolenic $\left(\mathrm{C}_{18: 3} ; \omega 3\right)$, eicosenoic $\left(\mathrm{C}_{20: 1}\right)$ and erucic acid $\left(\mathrm{C}_{22: 1}\right)$. Linoleic and linolenic are essential fatty acids that are not synthesized by our body.

Another important recommendation to judge the quality of oil is $\omega 6: \omega 3$ ratio which should lie between 5:1 to 10:1 (Johnson and Saikia 2009). Mustard oil fits well to this recommended range. Erucic acid is feared to be an agent of cardiac problems and should be less than $2 \%$ in edible oil as per guidelines of WHO. High level of erucic acid is of industrial use. Development of canola type (containing less than $2 \%$ erucic acid in oil and less than $30 \mu$ moles glucosinolates per gram defatted oilseed meal) varieties is a great achievement of Brassica breeders.

The mustard defatted meal is used as animal feed. It contains various phenolic compounds (bioactive secondary plant metabolites) including polyphenols, carotenoids and flavonoids (Ballesta et al., 2015) that contribute to diverse nutraceutical potential such as antimicrobial, antioxidant, antiinflammatory, antitumor and anti-carcinogenic effects (Sharma et al., 2016). Besides fats they contain vitamins, minerals, fibre and also a large number of novel phytochemicals, some of which provide protection against carcinogenesis (Seyis 2012).

The cake is also a rich source of proteins (35$40 \%$ ). However, still it is not preferred as protein supplement to animals to eliminate protein malnutrition due to presence of some anti-nutritional compounds viz., Glucosinolates (2-3\%), Tannin (1.6-3.1\%), Sinapine (1-1.5\%), Phytic acid (3-6\%). All these constituents are known to adversely affect the health of humans and animals. There is need for upgrading the cakes for further incorporation into foods and food products.

One of the major important objectives of the Brassica breeding programme in India is to improve oil and seed meal quality and a lot of progress has already been made and still being made by the rapeseed-mustard breeders with the development of double low " 00 " Indian mustard varieties with erucic acid $<2 \%$ and glucosinolate content $<30 \mu \mathrm{mole} / \mathrm{g}$ in defatted seed meal and also to achieve the balanced ratio of SFA/MUFA/PUFA and $\omega 6 / \omega 3$.

During the last 10 years, a significant interest have also aroused among the scientists in bioactive compounds present in many plants and food materials with strong antioxidant activity to reduce the free radical production that causes cell damage in the biological process (Sharma et al., 2017).

During 2017-18, a large number of germplasm were tested under All India Cordinated Research Project on Rapeseed Mustard (AICRP-RM) programme for quality traits viz oil content, fatty acid profiling, $\omega 6: \omega 3$ ratio, oil stability index $(18: 1 / 18: 2)$. Seed meal of these genotypes were also evaluated for protein, limiting amino acids viz, methionine and tryptophan, phytic acid, total antioxidant activity, DPPH free radical scavenging activity, total flavanoids and $\beta$-carotene content. 


\section{Materials and Methods}

\section{Source of plant material}

The seed samples of twenty four of IVT/AVT entries from AICRP-RM trials (2017-18) were used for various estimations. The estimations was done separately at five locations i.e. Bharatpur, Ludhiana, Hissar, Kangra, and Pantnagar,

\section{Estimation of oil by Soxhlet method}

Finely crushed weighed seed material of $2 \mathrm{~g}$ was put into a thimble and placed into the extractor of soxhlet apparatus after placing cotton at the bottom. A piece of cotton was placed at the top to evenly distribute the solvent as it dropped on the sample during extraction. Petroleum ether was added in the flask and extracted the oil for six hours (AOAC 1970). Allowed to cool and evaporated on water bath to remove last traces of the solvent. Kept the extraction flask in oven at $70^{\circ} \mathrm{C}$ for $10 \mathrm{~min}$, then transferred it to desiccator and cooled at room temperature. Weighed the flask and repeated the heating and cooling until constant weight was achieved.

\section{Estimation fatty acid methyl esters on GC}

$2 \mathrm{ml}$ toluene and $4 \mathrm{ml}$ dried methanolic- $\mathrm{H}_{2} \mathrm{SO}_{4}$ (99:1) were added to $20 \mathrm{mg}$ oil sample, vortexed and passed $\mathrm{N}_{2}$ for 2 minutes to get rid off moisture (Christie, 1990). Refluxed for 12 hrs at $50^{\circ} \mathrm{C}$ and cooled, then added $2 \mathrm{ml} \mathrm{NaCl}$ (4\%) solution, $2 \mathrm{ml} \mathrm{KCl} \mathrm{(4 \% )} \mathrm{solution} \mathrm{and} 20$ $\mathrm{ml} \mathrm{n}$-Hexane. Vortexed and separated out $\mathrm{n}$ Hexane layer. Added $4 \mathrm{ml} \mathrm{Na}_{2} \mathrm{CO}_{3}(4 \%) / \mathrm{KCL}$ (4\%) solution, vortexed and separated out hexane layer. Concentrated to one layer on vacuum using roto evaporator and injected $1 \mu 1$ of upper layer in split mode to injection port $\left(230^{\circ} \mathrm{C}\right)$ of $\mathrm{GC}$ equipped with ramps having column BP-20 (SGE) at 225 to $250^{\circ}$ Cusing $\mathrm{N}_{2}$ as carrier gas and detected peak with the help of FID detector at $250^{\circ} \mathrm{C}$.GC was calibrated with standards of methyl ester of palmitic, stearic, oleic, linoleic linolenic, eicosenoic and erucic acid.

\section{Determination of protein by micro- kjeldahl's method}

Weighed $100 \mathrm{mg}$ of the sample, transferred to a $30 \mathrm{ml}$ digestion flask. Add $1.9 \pm 0.1 \mathrm{~g}$ potassium sulphate and $80 \pm 10 \mathrm{mg}$ mercuric oxide and $2 \mathrm{ml}$ conc (AOAC 1965) $\mathrm{H}_{2} \mathrm{SO}_{4}$ to the digestion flask. Boiling chips were also added and sample was digested till the solution becomes colourless. After cooling the digest, diluted it with a very small quantity of distilled ammonia-free water and transferred to the distillation apparatus. The Kjeldahl flask was then rinsed with successive small quantities of water. Place a $100 \mathrm{ml}$ conical flask containing $5 \mathrm{ml}$ boric acid solution and a few drops of indicator with the tip of the condenser dipping below the surface of the solution. Add $10 \mathrm{ml}$ of sodium hydroxidesodium thiosulphate solution to the test solution in the apparatus. After distillation collect $15 \mathrm{ml}$ ammonia on boric acid. Rinsed the tip of the condenser and titrate the solution against the standard acid until the first appearance of violet colour. Run a reagent blank with an equal volume of distilled water and subtracted the titration volume from that of sample titer volume.

\section{Estimation of glucosinolate content by tetra chloropalladate method}

200mg oven dried seeds were crushed then transferred to screw-capped tubes and kept overnight at $50^{\circ} \mathrm{C}$ (Kumar et al., 2004). Add $300 \mathrm{ml}$ of $80 \%$ methyl alcohol in to the tubes. Keep the tubes on water bath at $70^{\circ} \mathrm{C}$ for 5 min. After cooling added $2 \mathrm{ml}$ double distilled water. Centrifuge at $5000 \mathrm{rpm}$ for 5 minute. Take $5 \mu 1$ of supernatant from upper layer on 
ELISA plate. Add $300 \mu \mathrm{l}$ of $0.002 \mathrm{M}$ sodium tetra chloropalladate. Mixed and put in oven at $70^{\circ} \mathrm{C}$ for 30 minute. Read at $405 \mathrm{~nm}$ on ELISA READER.

\section{Estimation of Phytic acid}

Freshly ground sample $(0.5 \mathrm{~g})$ was extracted with $25 \mathrm{ml}$ of $0.2 \mathrm{~N} \mathrm{HCL}$ for $3 \mathrm{hrs}$ on a shaker (Haug et al., 1983). After shaking, it was filtered through Whatman No. 1 filter paper. An aliquot $(0.5 \mathrm{ml})$ of the above extracted sample was taken in a test tube and $0.9 \mathrm{ml}$ of distilled water was added. To all the tubes add $1 \mathrm{ml}$ of ferric ammonium sulphate was added and then placed in boiling water bath for 30 minutes. One $\mathrm{ml}$ of the supernatant was transferred to another test tube and added 1.5 $\mathrm{ml}$ of bipyridine solution. The absorbance was measured at $519 \mathrm{~nm}$ against distilled water as blank. Different concentration of Sodium Phytate solution containing 30 to $50 \mu \mathrm{g}$ of Phytic acid was taken to make standard curve.

\section{Statistical Analysis}

All experiments were performed in triplicate. Data obtained were analyzed.

\section{Results and Discussion}

Biochemical traits exhibited broad variability among the different entries used in the current study (Table 1). The oil content ranged from $35.54 \%$ (LES-54) to $40.96 \%$ (KRANTI). The promising genotypes having high oil content were KRANTI (40.96 \%), NRCHB-101 $(40.16 \%)$. The present findings are similar as reported earlier (Prem et al., 2012). The oil stabilty index is the ratio of oleic acid to linoleic acid. Higher the OSI, longer is the shelf life of oil. The range of OSI varied from 0.79 (LES-54) to 1.34 (RL-1359(ZC). In the present study the promising genotypes having high OSI were RL-1359(ZC), RH749(ZC), PDZ-5, PDZ-1. The gas chromatographic analysis revealed that erucic acid in the mustard oil of various genotypes was in the range from $0.31 \%$ (CJRB-1661) to $49.79 \%$ (RL-1359. The genotypes of quality mustard having erucic acid $<2 \%$ were PM-29, LES-54, LES-55, PM-30, PDZ-7, CJRB-1661, PDZ-8, RLC-2, PDZ-4, PM-21, PDZ-1, PDZ5, PM-29 and RLC-3. High erucic acid content reported to be undesirable for human consumption leading to fibrotic changes in myocardium and increased adrenal cholesterol level (Aaes-Jorgensen 1972). The glucosinolate content varied from 16.20 to $103.96 \mu \mathrm{mol} / \mathrm{g}$ (KRANTI). The promising genotypes having glucosinolate content less than $30 \mu \mathrm{mol} / \mathrm{g}$ were CJRB-1661, PDZ-8, PDZ-4, PDZ-1, PDZ-5, RLC-3. Glucosinolate degradation forms various degradative products as per the ambient conditions like isothiocyanates. The high intake of Brassica vegetables is directly associated with a decreased risk of cancer of the lung, stomach, colon, and rectum due to the presence of glucosinolates (Poppel et al., 1999). In India, oil obtained from traditional mustard seed contains high amounts of erucic acid (40-57\%) and glucosinolate $(80-160 \mu$ mole $)$ per gram of defatted seed meal (Agnihotri and Kaushik 2002). Erucic acid and glucosinolates are antinutritional compounds having numerous ill effects on health of humans as well as animals, thus needed to be reduced to lower acceptable limits for rendering it safe for humans and animals consumption.

Omega ratio of none of the genotypes fall under the recommended value of 5-10. However, in present findings $\omega 6$ : $\omega 3$ ratio was fairly better in PDZ-1 (3.46), PM-29 (3.35), PDZ-7 (3.16), PM-21 (3.13) and PDZ-8 (3.13). Same findings were reported by Kumar et al., (2014), who compared ratios of SFA/MUFA/PUFA and $\omega 6 / \omega 3$ in Rapeseedmustard, Soyabean, Groundnut, Sunflower, and found that no other oil contains suitable 
ratios of SFA/MUFA/ PUFA and $\omega 6 / \omega 3$ ratios as per international recommendations 1:1-3:1 and 5-10 respectively except brassica.

In the current study of twenty four genotypes of Indian Mustard showed a significant variation of protein content in a narrow range from $34.86 \%$ to $38.79 \%$. The promising genotypes having high protein content were PM-21 (38.22\%), RLC-2 (38.48\%), PM-30 $(38.79 \%)$ and RGN-73(38.25\%). Mustard meal contains high protein content of approximately $40 \%$ and a nutritional study revealed that mustard protein has a remarkably well-balanced amino acid composition (Etten et al., 1967). The crude protein of defatted mustard meal is of high biological value having appreciable amount of albumin, glutelin, globulin (Klockeman et al., 1997).

Phytate is very important compound used in mineral storage, is a cation salt of phytic acid (myo-inositol hexa phosphoric acid). In this study phytic acid content was found to be varied from $1.77 \%$ in LES-55 to $2.84 \%$ in PM-30. Although it an anti-nutrient because it chelates divalent minerals and reduces their physiological availability (Hurrell, 2003), but it also possesses positive nutritional role as it acts as an anti-oxidant and anti-cancer agent.The present investigation are in agreement with the previous study reported phytic acid from 0.9 to $12.8 \mathrm{~g} \mathrm{~kg}^{-1}$ in seed meal (Lickfett et al., 2016) (Fig. 1).

Table.1 Pearson correlation

\section{Correlations}

Correlations

\begin{tabular}{|c|c|c|c|c|c|c|c|c|}
\hline & & OIL & $\mathrm{OSI}$ & $E A$ & OMG & TOTPROT & GSL & PA \\
\hline \multirow[t]{3}{*}{$\overline{\mathrm{OIL}}$} & Pearson Correlation & $\overline{1}$ & $.578^{* 1}$ & $.661^{* 1}$ & $.700^{* x}$ & $.673^{* \mathrm{~A}}$ & $.672^{* 2}$ & $.679^{* 1}$ \\
\hline & Sig. (2-tailed) & 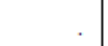 & .003 & .000 & .000 & .000 & .000 & .000 \\
\hline & $\mathrm{N}$ & 24 & 24 & 24 & 24 & 24 & 24 & 24 \\
\hline \multirow[t]{3}{*}{ OSI } & Pearson Correlation & $.578^{\star 1}$ & 1 & .386 & $.412^{\star}$ & .397 & .394 & .399 \\
\hline & Sig. (2-tailed) & .003 & . & .062 & .045 & .055 & .057 & .053 \\
\hline & $\mathrm{N}$ & 24 & 24 & 24 & 24 & 24 & 24 & 24 \\
\hline \multirow[t]{3}{*}{ EA } & Pearson Correlation & $.661^{* 2}$ & .386 & 1 & $.999^{* 1}$ & $1.000^{* *}$ & $1.000^{* * 2}$ & $1.000^{*}$ \\
\hline & Sig. (2-tailed) & .000 & .062 & . & .000 & .000 & .000 & .000 \\
\hline & $\mathrm{N}$ & 24 & 24 & 24 & 24 & 24 & 24 & 24 \\
\hline \multirow[t]{3}{*}{ OMG } & Pearson Correlation & $.700^{* 1}$ & $.412^{*}$ & $999^{* 1}$ & 1 & $.999^{\star *}$ & $.999^{\star *}$ & $1.000^{\star 2}$ \\
\hline & Sig. (2-tailed) & .000 & .045 & .000 & . & .000 & .000 & .000 \\
\hline & $\mathrm{N}$ & 24 & 24 & 24 & 24 & 24 & 24 & 24 \\
\hline \multirow[t]{3}{*}{ TOTPROT } & Pearson Correlation & $.673^{\text {*a }}$ & .397 & $1.000^{* * 2}$ & $.999^{* 1}$ & 1 & $1.000^{* * 2}$ & $1.000^{\text {* }}$ \\
\hline & Sig. (2-tailed) & .000 & .055 & .000 & .000 & . & .000 & .000 \\
\hline & $\mathrm{N}$ & 24 & 24 & 24 & 24 & 24 & 24 & 24 \\
\hline \multirow[t]{3}{*}{$\overline{G S L}$} & Pearson Correlation & $.672^{\star 2}$ & .394 & $1.000^{* * 2}$ & $.999^{* x}$ & $1.000^{* *}$ & 1 & $1.000^{\text {* }}$ \\
\hline & Sig. (2-tailed) & .000 & .057 & .000 & .000 & .000 & . & .000 \\
\hline & $\mathrm{N}$ & 24 & 24 & 24 & 24 & 24 & 24 & 24 \\
\hline \multirow[t]{3}{*}{$\mathrm{PA}$} & Pearson Correlation & $.679^{* 1}$ & .399 & $1.000^{* * x}$ & $1.000^{*=1}$ & $1.000^{* 2 *}$ & $1.000^{* *}$ & 1 \\
\hline & Sig. (2-tailed) & .000 & .053 & .000 & .000 & .000 & .000 & . \\
\hline & $\mathrm{N}$ & 24 & 24 & 24 & 24 & 24 & 24 & 24 \\
\hline
\end{tabular}

${ }^{* \star}$. Correlation is significant at the 0.01 level (2-tailed).

${ }^{\star}$. Correlation is significant at the 0.05 level (2-tailed). 
Table.2 Eigen values of cluster analysis

\begin{tabular}{|l|l|l|l|l|l|l|l|l|}
\hline \multicolumn{2}{|l|}{ Eigen values } & & & & & & & \\
\hline & Number & $\begin{array}{l}\text { Eigen } \\
\text { value }\end{array}$ & Percent & Percent & $\begin{array}{l}\text { Cum } \\
\text { Percent }\end{array}$ & $\begin{array}{l}\text { Chi } \\
\text { Square }\end{array}$ & DF & \multicolumn{2}{|l|}{ Prob>ChiSq } \\
\hline 1 & 5.7305 & 81.864 & ++++++++ & 81.864 & 1390.39 & 16.444 & $<.0001$ & \\
\hline 2 & 0.9306 & 13.294 & + & 95.159 & 1193.17 & 19.332 & $<.0001$ & \\
\hline 3 & 0.3389 & 4.841 & & 100 & 1071.62 & 13.954 & $<.0001$ & \\
\hline 4 & 0 & 0 & & 100 & 19.542 & 9 & 0.021 & \\
\hline 5 & 0 & 0 & & 100 & 9.001 & 4.999 & 0.109 & \\
\hline 6 & 0 & 0 & & 100 & 3.155 & 1.999 & 0.2064 & \\
\hline 7 & 0 & 0 & & 100 & 0 &. &. & \\
\hline & & & & & & & & \\
\hline
\end{tabular}

Fig.1 Genotypes screening

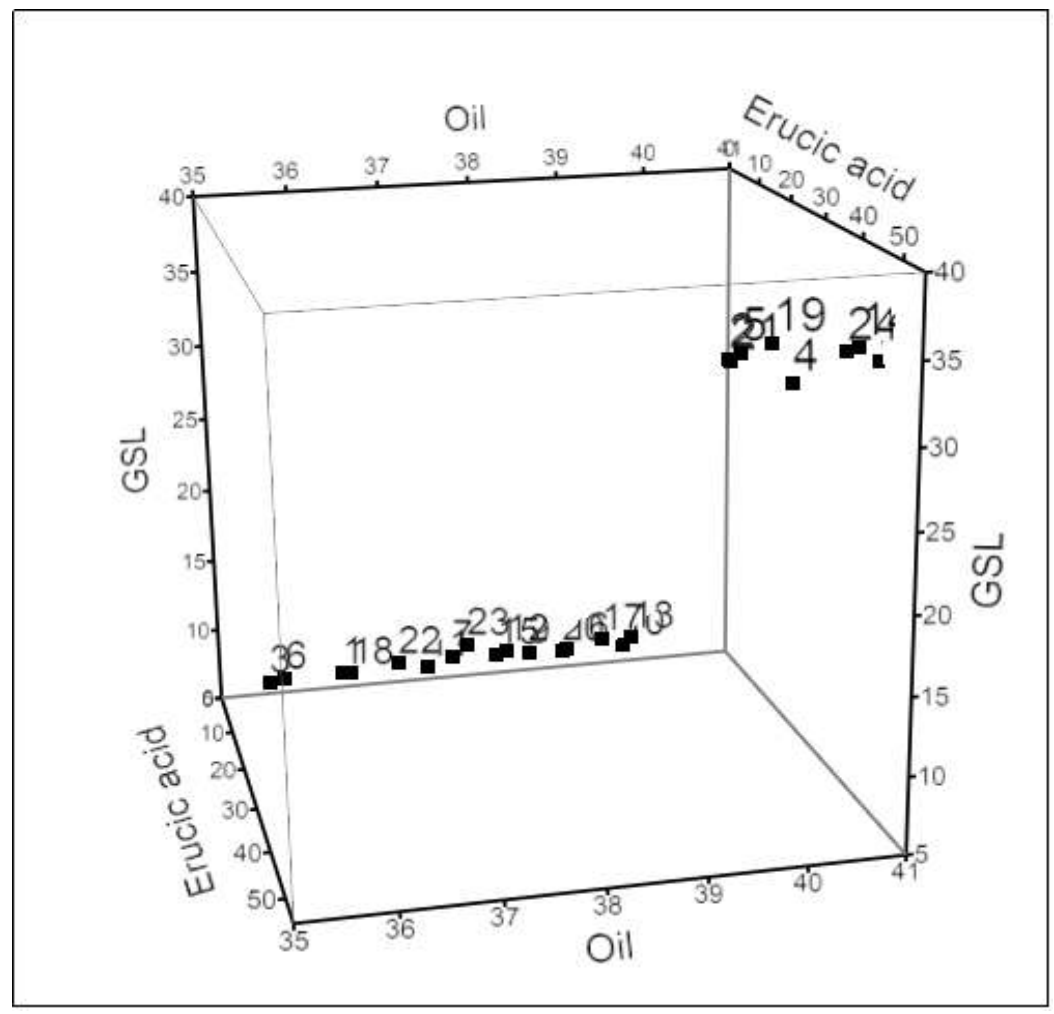


Fig.2 PCA analysis (A \& B)
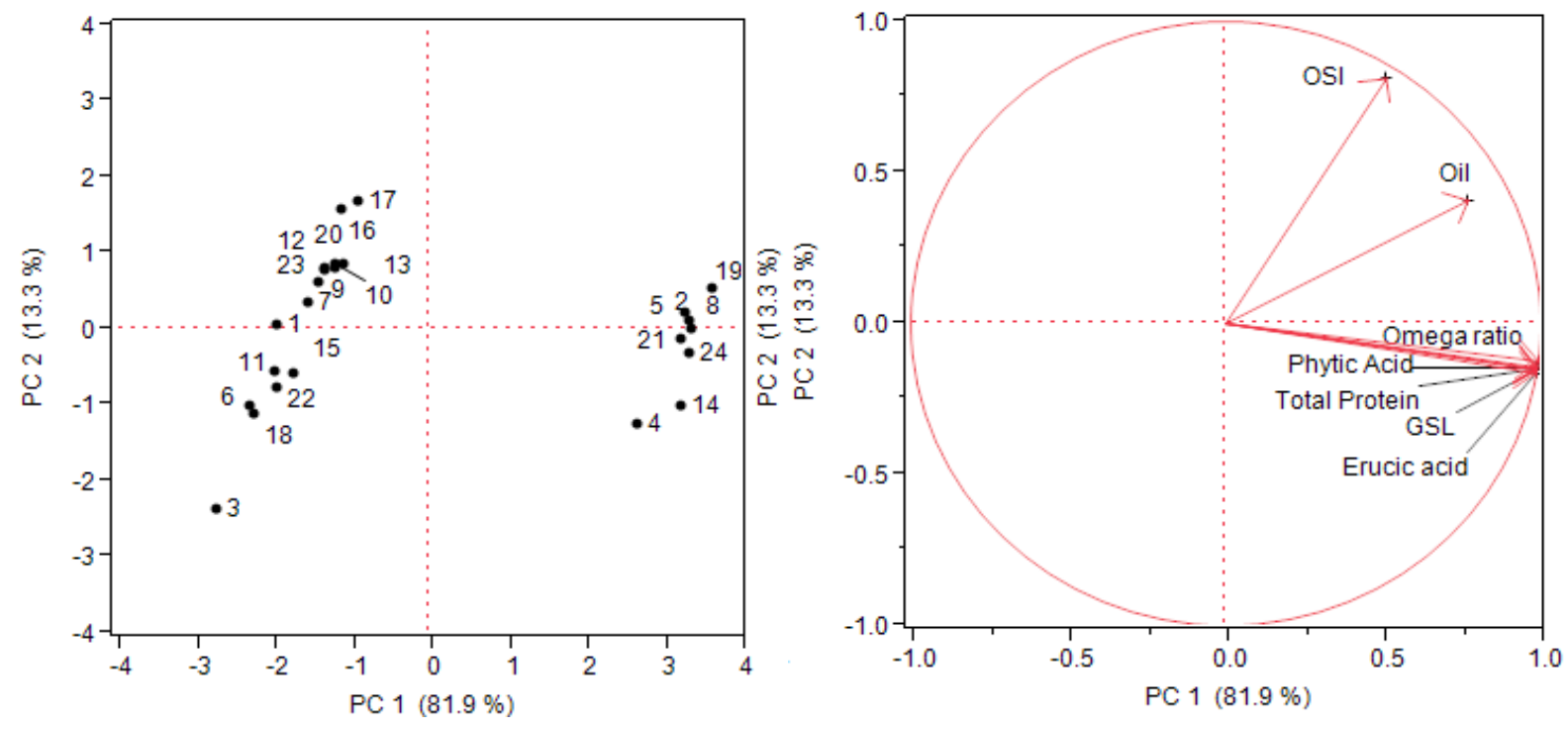

Fig.3 Two way cluster analysis in brassica genotype
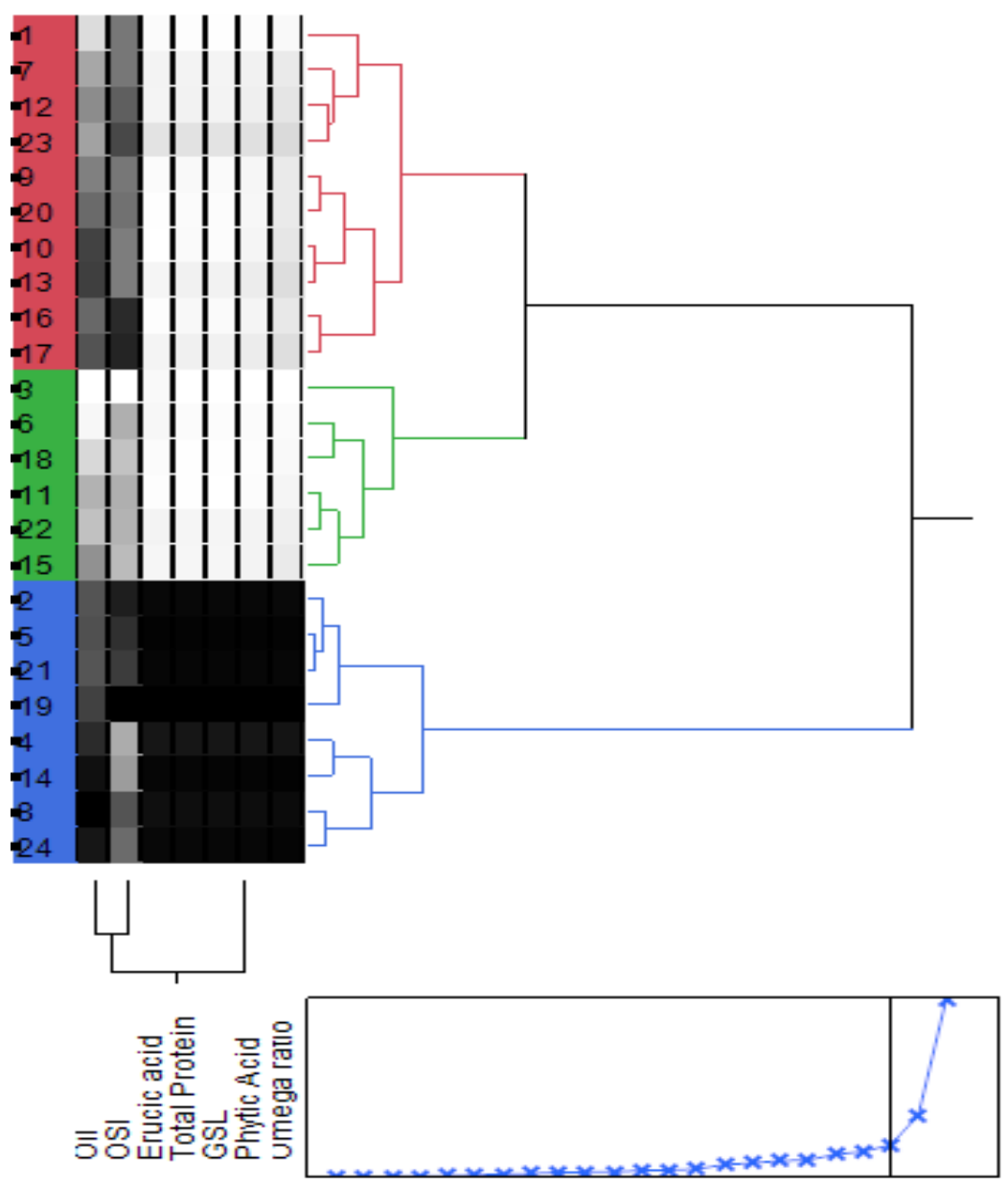


\section{Multivariate analysis}

Principal Component Analysis (PCA) is a useful statistical technique which has found application in reduction of the original variables in oil content, erucic acid, protein content and contents to smaller number of variables i.e. principal components which reveal the interrelationships between the different variables. The loading and scatter plot of mustard genotypes were studied using principal PCA and are shown in Figure 2(a) and (b), respectively. In the PCA, the length, direction and the angles between the lines indicate correlation between the variables or between variables and principal component axes (e.g., $\alpha=0^{\circ}$ and $/$ or $180^{\circ}$ and $\mathrm{r}=1 ; \alpha=90^{\circ}$ and $\mathrm{r}=0$ ). The first principal component ( $\mathrm{PC} 1)$ had the highest Eigen value of 5.73 and accounted for $81.9 \%$ variability in the data set, while second principal component (PC2) had eigen value of 0.93 and accounted for $13.3 \%$ variability (Table 2). All parameters occupied the right side in the biplot. Further among the parameters oil stability index (OSI) and oil percent were observed on the right upper side in the biplot with high positive loading for both $\mathrm{PC} 1$ and $\mathrm{PC} 2$, while phytic acid, glucosinolate (GSL), erucic acid, total protein and omega ratio were observed with slightly lesser positive loadings on the right lower side of the biplot. The PCA clearly suggests that phytic acid and GSL are having significant positive correlation. However, negative correlation was observed between oil percent and phytic acid, GSL. Similarly, it is also observed that most promising genotypes with high amount of oil stability index (OSI) and oil percent and low amount of phytates occupies the upper right side of the scatter plot of brassica genotypes (Fig. 2b).

Correlations were computed among seven biochemical parameters on data for 24 genotypes. The Pearson correlation indicates that most of the variables have positive correlation. Significant positive relationship can be seen between phytic acid, glucosinolates, total proteins and erucic acid table $1(>0.30)$. However moderate negative correlation was observed between oil \& total protein content. The results suggest that all the correlations were statistically significant and were greater or equal to $\mathrm{r}=+.50, \mathrm{p}<.05$, two-tailed.

\section{Two way cluster analysis}

The studied Indian mustard genotypes were categorized based on their biochemical constituents using the two way cluster analysis which is shown in Figure 3. The twoway cluster analysis broadly separated the brassica genotypes into three clusters. Among these three clusters the cluster III which contains RH-749, RGN-73, RGN-73, RL1359, NRCHB-101, Kranti were found with higher amount of GSL, erucic acid, phytic acid, total protein along with moderate amount of oil index stability. The lowest amount of GSL, erucic acid, phytic acid, total protein were observed in cluster II which contains LES-54, LES-55, PM-29, PDZ-8, PDZ-6, PM-21. Cluster I (PM-30, RLC-2, PDZ-7, RLC-3, CJRB-1661, PDZ-4, PDZ-1, PDZ-5) was observed with the lowest content of GSL compared to all other clusters.

In conclusion, the study confirmed the significant genetic variability in brassica kernels with respect to oil content, glucosinolates, total protein, omega ratio, oil stability index and PA. Among the studied brassica genotypes PM-30, RLC-2, PDZ-7, RLC-3, CJRB-1661，PDZ-4，PDZ-1，PDZ-5 were found with lower amount of gsl, erucic acid, phytic acid, total protein along with moderate amount of oil content.

The positive correlation between GSL, PA and protein content revealed that concurrently 
improvements of these nutritional parameters are possible. Further, substantial genetic variability coupled with high heritability and weak association of oil contents with glucosinolate and phytate contents suggested that it is possible to breed oil content dense cultivars with low phytate contents.

\section{Acknowledgement}

The authors are grateful to Indian council of Agricultural Research for funding the work and the plant breeders for sharing seeds of genotypes used in this study. The authors have no conflict of interest.

\section{References}

Aaes-Jorgensen E (1972) Nutritional value of rapeseed oil. pp. 301-353. In: Rapeseed Cultivation, Composition, Processing and Utilization, by Appelqvist, L A and Ohlson R, Elsevier, Amsterdam.

Agnihotri A and Kaushik N (2002) Quality considerations in edible oilseeds: rapeseed and mustard. In: Oilseeds and oils: research and development needs. Rai M, Singh $\mathrm{H}$ and Hedge, DM (ed) Hyderabad, An Indian Society of Oilseeds Research Publication: 315-326.

AOAC (1965) Official Methods of Analysis of Association of Official Analytical Chemists. $6^{\text {th }}$ Edition, Washington, D.C.

AOAC (1970) Official Methods of Analysis of Association of Official Analytical Chemists, 11th edn Washington, DC.

Christie WW (1990) Preparation of methyl esters-Part 1. Lipid Tech, 2, 48.

DAC(2017) Directorate of Economics and Statistics (DES), Department of Agriculture and Cooperation (DAC) and Department of Commerce (DoC)
Commodity Profile for Pulses-March, 2017(As on 24.03.2017). Pp. 9.

Etten C H, Kwolek WF, Peters JE, Barclay AS (1967) Plant seeds as protein source for food and feed: Evaluation based on amino acid composition of 379 Species. J Agric Food Chem 53: 162-166.

Haug W and Lantzsch H J (1983) Sensitive method for the rapid determination of phytate in cereal and cereal products. $J$ Sci Food Agri 34(12): 1423-26.

Hurrell RF (2003) Influence of vegetable protein sources on trace element and mineral bioavailability. Nutrition Journal 133: 2973S-2977S.

Johnson S and Saikia N (2009) Fatty acids profile of edible oils and fats in India. Centre for Science and Environment. New Delhi, CSE: 32.

Klockeman DM, Toledo $\mathrm{R}$ and Sims KA (1997) Isolation and characterization of defatted canola meal protein. $J$ Agric Food Chem 45(10): 3867-3870.

Kumar S, Singh D and Dutta M (2014) Quality characteristics in rapeseedmustard and role of some antinutritional factors in plant defense: future strategies. J Oilseed Brassica 5: 87-95.

Kumar S, Yadav SK, Chauhan JS, Singh AK, Khan NA and Kumar PR (2004) Estimation by complex formation between glucosinolates and tetrachloropalladate (II) using ELISA Reader. J Food Sci and Tech-Mysore 41: 63-65.

Lickfett T, Matthäus B, Velasco Land Christian M ((1999) Seed yield, oil and phytate concentration in the seeds of two oilseed rape cultivars as affected by different phosphorus supply. European Journal of Agronomy 11: 293-299

Martínez-Ballesta M, Moreno-Fernández DA, Castejón D, Ochando C, Morandini 
PA, Carvajal M (2015) The impact of the absence of aliphatic glucosinolates on water transport under salt stress in Arabidopsis thaliana. Frontiers Plant Sci. 6:524.

doi:10.3389/fpls.2015.00524.

Poppel VG, Verhoeven DT, Verhagen H, Goldbohm RA (1999) Brassica vegetables and cancer prevention, Epidemiology and mechanisms. $A d v$ Exp Med Biol. 472: 159-168.

Prem D, Gupta K, Sarkar G and Agnihotri A (2012) Determination of oil, protein and moisture content in whole seeds of three oleiferous Brassica species using near-infrared reflectance spectroscopy. Journal of Oilseed Brassica 3(2): 88-98.

Seyis (2012) Towards a canola quality resynthesized rapeseed (Brassica napurs L.): $B$. oleracea genotypes as a basic resource. The European Journal of Plant Science and Biotechnology 7 (Special issue 1): 33-37.

Sharma A, Kumar A, Meena HS, Singh D (2017) Chromatographic determination of Phenolics in Brassica juncea L. Asian J. Chem. 29:296-300.

Sharma A, Sharma A, Yadav P, Singh D (2016) Isothiocyanates in Brassica: Potential Anti-Cancer Agents. Asian Pac J Cancer Prev. 17(9):4507-451.

\section{How to cite this article:}

Anubhuti Sharma, Manoj Aacharya, H. Punetha, Sanjula Sharma, Nisha Kumari and Rai, P.K. 2019. Biochemical Characterization and Correlations in Brassica juncea Genotypes. Int.J.Curr.Microbiol.App.Sci. 8(01): 2408-2417. doi: https://doi.org/10.20546/ijcmas.2019.801.254 